\title{
The Viability of a Monetary Union in South America: Insights from Generalised Purchasing Power Parity Theory
}

\author{
Caroline Fosdike ${ }^{1}$
}

\begin{abstract}
South America has seen increased interest in interregional economic and political cooperation over the last decades. Inspired by the European Union, the Union of South American Nations (UNASUR) became the official body of regional integration in South America in 2008. Plans for a regional currency within the UNASUR have returned to the political agenda following a prolonged period of silence on the topic amid turbulences in the Eurozone. Spanning the period 19792012, this paper analyses the viability of a monetary union between nine UNASUR members from a generalised purchasing power parity (G-PPP) perspective. It finds evidence for a unique cointegrating relationship between the countries' monthly real exchange rates when the period of the Latin American debt crisis is omitted. The analysis provides support for monetary integration in that it shows the region to be economically interlinked. Nevertheless, adjustments to macroeconomic shocks appear asymmetric suggesting further economic integration is necessary for a monetary union to be viable.
\end{abstract}

\section{Introduction}

The creation of the Eurozone has triggered increased research interest in the feasibility of currency unions in several geographic areas. The reason for considering a common currency for a set of countries is that, under the right circumstances, a common currency maximises economic efficiency. Researchers who investigated the prospects of a monetary union in South America in the immediate years after the creation of the Eurozone have criticised the lack of necessary economic and political integration as potential factors impeding the efficiency of a common currency. Yet, the idea of a monetary union has attracted serious political interest in South America.

Recently, a major step towards political and economic integration in South America has been taken with the formation of the Union of South American Nations (Unión de Naciones Suramericanas, UNASUR) in 2008. Although the group's institutionalisation remains slow, continued integration efforts are likely to increase the potential efficiency gains from a monetary union. It is therefore the objective of this paper to re-evaluate the prospects of a monetary union for South America. Rather than relying on the standard optimum currency area (OCA) theory, this paper complements the existing literature by applying the theory of Generalised Purchasing Power Parity (G-PPP), developed by Enders and Hurn (1994). It thereby assesses whether the macroeconomic fundamentals underlying the real exchange rates of UNASUR members are sufficiently integrated to advocate the formation of a monetary union.

\footnotetext{
${ }^{1}$ Caroline Fosdike received a bachelor's degree in Economics at Maastricht University in 2015. She is currently working in Banking Supervision at the Bank of England. Contact: caroline@fosdike.co.uk
} 
Firstly, it builds the theoretical framework by providing some background on the process of political and economic integration in South America focusing on institutional developments. It furthermore reviews the existing literature on the assessment of the feasibility of regional monetary integration. Secondly, it reviews G-PPP theory as developed by Enders and Hurn (1994). Thirdly, it empirically tests G-PPP in South America by means of unit root and cointegration tests during the sample period of 1979 to 2012 . It thereafter proposes a reduced sample excluding the period of the Latin American debt crisis in the early 1980s. Fourthly, it provides a discussion of the empirical results before pointing out the paper's limitations. Finally, it concludes that there is clear evidence that the UNASUR constitutes a potential common currency area from a pure G-PPP perspective. Nevertheless, persisting political and economic instabilities across the region negatively affect monetary integration considerations and the benefits from the formation of a monetary union thus remain unclear.

\section{Theoretical framework}

\subsection{Process of political and economic integration in South America}

The history of regional integration in South America dates back to the early nineteenth century when Simon Bolivar, leader of Latin America's independence movement, shared his vision of a South American republic (Council of Hemispheric Affairs, 2013). Nevertheless, the institutionalisation of the integrating process did not start until 1948 when the Organization of American States (OAS) was established, constituting a political, juridical, and social governmental forum promoting democracy, human rights, security and development (OAS, 2015).

The first regional and sub-regional economic blocs formed in the 1960s, notably the Latin American Free Trade Association (ALALC), and the Andean Community of Nations (CAN), formerly known as Andean Pact. The customs union CAN also comprises a financial arm known as the Andean Development Corporation (CAF) which serves as a development bank in Latin and South America covering 17 Latin American and Caribbean countries (CAF, 2015). In 1991 the Common Market for the South (Mercosur) was created to enable the free movement of goods, services, capital and people among its member states and establish a common trade policy. Mercosur comprises five South American countries neither of which are members of CAN (figure 1). (Peña, 2009).
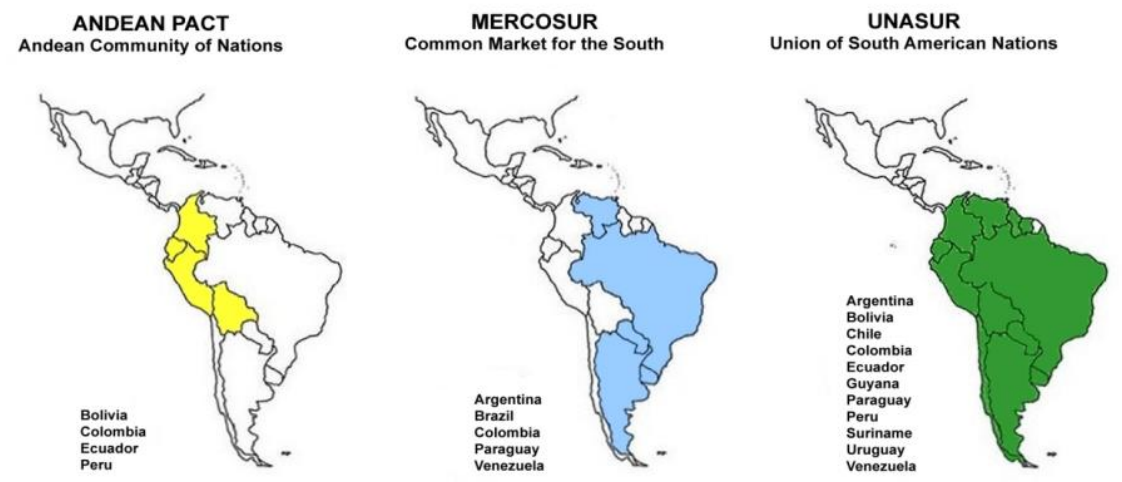

Figure 1: South American trade alliances. Source: Hall, Eileen (2012)

Increasing inter-connectedness in the region and the acknowledgment of the large area's potential comprised under the different trade agreements led to the foundations of the intergovernmental union UNASUR. Through integrating the two pre-existing regional trade unions (figure 1), Mercosur and CAN,

$2 \quad$\begin{tabular}{l|l} 
Marble \\
Research \\
Papers
\end{tabular} 
the UNASUR further develops the institutional framework for South America. By superseding sole economic cooperation it adds a political dimension to the integration process. (Peña, 2009)

The UNASUR's founding treaty was signed by twelve member states, including Argentina, Bolivia, Brazil, Chile, Colombia, Ecuador, Guyana2, Paraguay, Peru, Suriname, Uruguay, and Venezuela. Mexico and Panama currently hold observer status. In its modelling after the European Union, the UNASUR is intended to promote cultural, social, political and economic integration in the region and develop a South American identity and citizenship. Some of the ambitious goals were the establishment of a continental free trade zone, a South American parliament, and a single currency. (UNASUR, 2014)

So far, the UNASUR mainly serves as a public forum for policy makers to establish political links, promote trade and inclusive social and human development. It is also a platform for proposing action plans for further integration. In contrast, the coexisting trade blocs CAN and Mercosur are based on concrete legal agreements. In an effort to strengthen the UNASUR's influence and ensure its longevity, permanent headquarters have been established in Quito, Ecuador and were inaugurated in December 2014.

In order to develop the internal market within the UNASUR, a stable currency without fluctuation risks offers advantages beyond the reduction of transactions costs for intra-UNASUR trade. Many UNASUR member countries have a history of unstable macroeconomic environments marked by high inflation, repeated currency devaluations and high indebtedness. Regional coordination of sustainable macroeconomic policies targeting low inflation, fiscal discipline, and a rejection of government spending financed by the central bank would counteract these weaknesses. Furthermore, a stable common currency would symbolise strength and thereby aid in enhancing economic and political stability. Credible, supranational institutions, such as a central bank and a mechanism providing for the coordination of fiscal policies would further support stability. Recognising these benefits, the member states originally had plans to form a monetary union within the UNASUR.

As a step towards monetary cooperation, the creation of a Banco del Sur (Bank of the South) was formalised in December 2007. The Bank is to serve as a regional financing facility to sponsor development projects and provide emergency assistance across the region. All UNASUR members were invited to join the Bank but only four countries have formally approved its charter (Argentina, Bolivia, Ecuador, and Venezuela). In contrast to the regionally criticised IMF and World Bank lending conditions, Banco del Sur lending was not to be conditional on deregulatory policy measures. The slow progress of the UNASUR member states' approval of the project underlines persisting resistance to further regional integration.

A factor influencing the climate of opinion on monetary integration has been the Eurozone crisis. The crisis highlighted that price stability does not necessarily guarantee financial stability. The mere introduction of a common currency does not replace the need for internal adjustment if it covers diverse states. Within UNASUR, economies are strikingly diverse. Figure 2 shows the respective output shares of the member countries in 2013. Brazil is clearly the dominant economy with an output share of $51 \%$, followed by Argentina (14\%), whilst Bolivia, Guyana, Paraguay, Suriname and Uruguay have shares below $1.5 \%$ of total output.

\footnotetext{
${ }^{2}$ Guyana and Suriname are concurrently members of the Caribbean Community (CARICOM) which has itself a vision to create a single market and economy to allow the free movement of goods, services, capital, and people.
} 
Figure 2: Member UNASUR's total GDP in

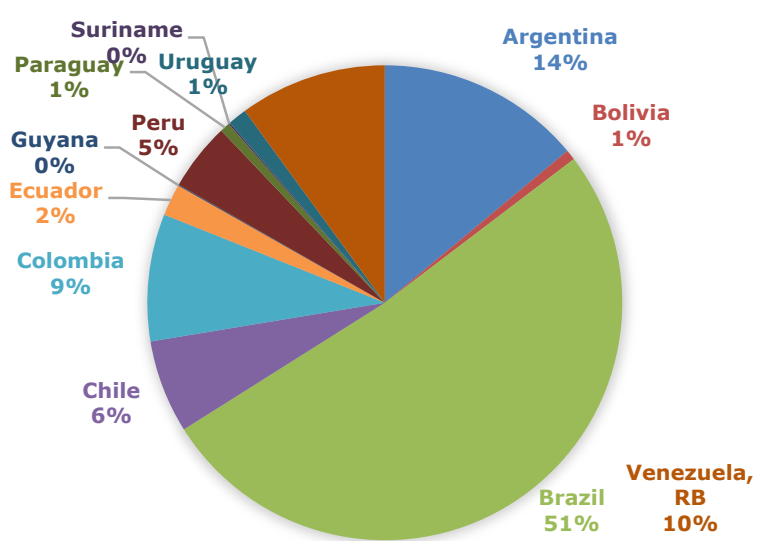

countries' output share of 2013.

Source: World Bank.

Comparing the UNASUR members' development stages on the basis of their GDP per capita levels in purchasing power parity terms further highlights the strong disparities (table 1). Based on data from 2013, the per capita GDP of the weakest country (Bolivia) is less than $30 \%$ that of the strongest (Chile). This suggests that the creation of a common currency would create pressures for large-scale fiscal transfers resulting in a slow and complicated integration process (Berg, Borensztein, \& Mauro, 2003).

Table 1: GDP per capita, PPP in 2013

\begin{tabular}{|l|l|}
\hline Country & GDP per capita, PPP \\
\hline Argentina & 17554.12 \\
\hline Bolivia & 6131.06 \\
\hline Brazil & 15037.46 \\
\hline Chile & 21911.30 \\
\hline Colombia & 12423.92 \\
\hline Ecuador & 10889.99 \\
\hline Guyana & 6545.93 \\
\hline Paraguay & 8092.67 \\
\hline Peru & 11774.19 \\
\hline Suriname & 16071.38 \\
\hline Uruguay & 19594.37 \\
\hline Venezuela, RB & 18198.37 \\
\hline Note: Data are in current international \$. \\
Source: World Bank
\end{tabular}

The strong variation in development stages of the UNASUR member states remains an obstacle to mutually beneficial integration. Policymakers in South America consequentially acknowledged the monetary policy lessons from the Eurozone and have since become more cautious in defining concrete integration plans. Despite initial political support for a common currency, plans were suspended in 2011 due to the negative experience from the Eurozone crisis.

Currently, the member states' exchange rate regimes and monetary policy arrangements vary widely. The choice of an exchange rate regime and can have significant implications not only for price and financial stability, and economic growth and development. (Berg, Borensztein, \& Mauro, 2003) Table 2 depicts the disparities in current exchange rate arrangements and monetary policy anchors in the UNASUR member states. Following the collapse of fixed exchange rates (Argentina, Brazil) in the 1990s,

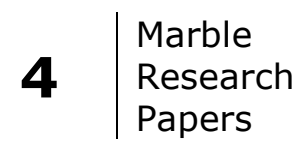


a trend toward the implementation of more flexible exchange rate regimes can be observed. (Frenkel \& Rapetti, 2010) Despite many South American countries having a monetary arrangement with the US dollar, dollarisation in place of a separate common currency is undesirable as the region is politically striving for establishing an identity independent of the United States.

Table 2: Exchange rate regimes and monetary policy frameworks. Source: IMF (2013).

\begin{tabular}{|l|l|l|}
\hline Country & Exchange Rate Regime & Monetary Policy Framework \\
\hline Argentina & Floating & Monetary aggregate target \\
\hline Bolivia & Stabilised arrangement with US\$ & No explicit target \\
\hline Brazil & Currency board & Inflation target \\
\hline Chile & Free floating & Inflation target \\
\hline Colombia & Floating & Inflation target \\
\hline Ecuador & US\$ (no separate legal tender) & No monetary policy autonomy \\
\hline Guyana & Stabilised arrangement with US\$ & No explicit target \\
\hline Paraguay & Other managed arrangement & Inflation target \\
\hline $\begin{array}{l}\text { Peru } \\
\text { Suriname }\end{array}$ & Floating & Inflation target \\
\hline $\begin{array}{l}\text { Uruguay } \\
\text { Venezuela, RB }\end{array}$ & Stabilised arrangement with US\$ & Inflation target \\
\hline
\end{tabular}

\subsection{Monetary integration assessment methods and literature review}

Monetary integration across sovereign states has long been subject of public debate and there are several aspects which contribute to the discussion on the viability of such supranational policy measures. Mundell (1961), McKinnon (1963), and Kenen (1969) are often referenced as the foundations of optimum currency area theory. Based on Mundell's framework, an optimum currency area (OCA) refers to a region in which a common currency maximises economic efficiency. Drawing upon the findings of several authors allows for a specification of OCA criteria including labour and capital mobility, trade openness, production and consumption diversification, fiscal integration, price and wage flexibility, similarities of inflation rates, financial market integration, and political integration. A large part of the literature on potential monetary unions examines the OCA criteria in order to conclude whether the benefits of monetary integration outweigh the costs.

Researchers, who have examined different combinations of South American countries within the scope of the OCA framework, have not found sufficient support to make the case for a monetary union. Berg, Borensztein, and Mauro (2002) follow a qualitative approach to examine different monetary regime options for South America. They conclude that due to the small volume of mutual trade, diverse economic shocks, and uncoordinated business cycles, the costs of a common currency are likely to outweigh its costs (Berg, Borensztein, Mauro, 2002). Similarly, Hochreiter, Schmidt-Hebbel, and Winckler (2002) conduct a literature review and analyse recent trends in monetary and exchange-rate regimes across the region. They find no evidence for long run sustainability of a monetary union due to low intraregional trade, idiosyncratic shocks, wide disparities in the political and institutional environment, and a lack of homogeneity in economic development (Hochreiter, Schmidt-Hebbel, Winckler, 2002). Examining external shocks and economic performance in countries belonging to existing or historic currency union, 
Edwards (2006) interprets that a common currency is not likely to economically strengthen the South American region.

Analyses evaluating a region's suitability for a monetary union based on the OCA framework often rely on ad hoc proxies, because the OCA criteria lack a unifying framework. This makes an evaluation difficult and may lead to inconclusive results instead of providing a clear answer as to whether a region is suitable for a common currency (Tavlas, 1994). For instance, a country may be open to trade towards a particular group of countries, suggesting a benefit from a fixed exchange rate. On the other hand, the country may also display factor immobility. In the presence of asymmetric shocks, exchange rate realignment would then be important as the production factors cannot exercise a stabilisation function by shifting across the countries. Due to these conflicting indications, clear normative implications are not easily obtainable under an assessment of OCA criteria.

Despite the fact that numerous authors have not found supporting evidence in favour of the formation of a monetary union in South America, existing research does not consider the viability of a monetary union within the regional bloc UNASUR. Instead, it focuses on different combinations and subgroups of South American countries. This is partially due to the fact that much of the existing research in the field has been conducted before the formation of the UNASUR. Hence, the distinct effects of the UNASUR, which has seen South American nations actively seeking to increase economic and political integration, are not included.

This paper takes a different approach by applying the theory of G-PPP based on Enders and Hurn (1994) to the UNASUR bloc using more recent data than previous analyses. The timeframe of the analysis spans from 1979 to 2014. The underlying assumption of G-PPP theory is that exchange rate movements have an important effect on monetary policies. The theory serves to assess whether exchange rate movements are similar enough to support a monetary union by investigating common trends among exchange rates. An existence of common trends would support a synchronisation of monetary policies, whilst an absence would make a monetary union undesirable.

The analysis thus seeks to identify whether the driving factors of the real exchange rates are sufficiently integrated across the UNASUR countries to advocate a common currency using cointegration and stability tests. It specifically seeks to clarify whether there is evidence for an equilibrium real exchange rate in the region based on the G-PPP framework and therefore a motivation for monetary integration. The paper thereby contributes to the existing literature on monetary policy choices for South America by complimenting the discussion with a G-PPP perspective. It adds the necessary empirical value to current political considerations, which tend to be strongly influenced by negative experiences in the Eurozone.

\section{Methodology}

This section briefly describes the G-PPP theory and estimation procedure. More details on the theory can be found in Enders and Hurn (1994). The theory of G-PPP is based on the assumption that the macroeconomic fundamentals underlying the real exchange rates tend to be non-stationary so that the real exchange rates themselves are also generally non-stationary. If the macroeconomic fundamentals across a group of countries are sufficiently interrelated, the real rates will share common trends and the country grouping of the real exchange rates may be stationary. Consequently, a natural currency area among the country grouping will be implied based on commonalities in the economic drivers of the
$6 \quad$\begin{tabular}{l|l} 
Marble \\
Research
\end{tabular}
Papers 
members' exchange rates. If the group of countries does not share the same real disturbances, or if the adjustment speed is very different or very slow, there is no motivation from a G-PPP perspective, to advocate a common currency.

More formally, Enders and Hurn (1994) denote the long-run equilibrium relationship between the $m$ bilateral real exchange rates of $m+1$ countries in the domain of a potential currency area within an $n-$ country world as

$$
r_{12 t}=\beta_{13} r_{13 t}+\beta_{14} r_{14 t}+\cdots+\beta_{1 m} r_{1 m t}+e_{t}
$$

where $r_{1 i t}$ denotes the logarithmic RERs in period t between the base country 1 and country $i$, $\beta_{1 \mathrm{i}}$ is the coefficient of the cointegrating vector and $e_{t}$ is an error term. At least one linear stationary combination of the RERs exists if bilateral RERs within a vector share common trends. Consequently, the RERs of the group of countries considered will be cointegrated. If this interrelationship among the underlying economic fundamentals is sufficiently strong, G-PPP will hold. Based on G-PPP theory, the country grouping can then be considered to constitute a currency area.

It is important to point out here that if each country's currency was pegged to a common currency, the RERs would be constant across the bloc. This would shift the focus of the analysis solely on inflation differentials. (Wilson \& Choy, 2007) The mentioning of this point is particularly relevant in this analysis since, as outlined above, many of the UNASUR members had or continue to have a monetary agreement with the US dollar. Yet, pegs to the dollar still leave ample room for variation in the real rates due to differences in the duration and extent of the pegging periods. Therefore, the analysis remains valid.

\section{Testing G-PPP in South America}

The analysis considers the natural logarithm of the real effective exchange rates (REERs) of the UNASUR members against a basket of currencies including monthly data from M12 1979 to M7 2014. The data is obtained from the IMF's International Financial Statistics database, where, given a set of weights for the home country $i$ on its trade partners $\left(W_{i j}\right.$ for $\left.j \neq i\right)$, the REER index of country $i$ is based on the following formula:

$$
\operatorname{REER}_{\mathrm{i}}=\pi_{\mathrm{j} \neq \mathrm{i}}\left(\frac{\mathrm{P}_{\mathrm{i}} \mathrm{R}_{\mathrm{i}}}{\mathrm{P}_{\mathrm{j}} \mathrm{R}_{\mathrm{j}}}\right)^{\mathrm{W}_{\mathrm{i}}}
$$

where $j$ denotes the trading partners, $P$ denotes the consumer price index, and $R_{i}$ and $R_{j}$ refer to the bilateral nominal exchange rates of country $i$ and $j$ against the US dollar (measured in US dollar per local currency). The index is thus a geometric weighted average of bilateral exchange rates between country $i$ and its trade partners. (Bayoumi, Lee, \& Jayanthi, 2006) Due to data limitations Argentina, Peru, and Suriname are excluded from the analysis. 


\subsection{Unit root testing and cointegration analysis}

\subsubsection{Empirical results complete sample}

The first step of the analysis is to establish whether the real exchange rates are individually nonstationary. Initial visual inspection of the UNASUR members' REERs suggests that the REERs are nonstationary in levels and stationary in first differences. Formal Dickey-Fuller tests are performed, testing the null hypothesis of a unit root against the alternative of stationarity. The test results indicate that the null hypothesis of a unit root in the REER series cannot be rejected at any reasonable significance level for any country in the sample except Bolivia ( $p$-value $=0.0002$ ). When the augmented version of the Dickey-fuller test is applied with one specified lag, the null of a unit root can only be rejected for Bolivia and Brazil, with $\mathrm{p}$-values of 0.0005 and 0.0563 respectively.

Given this result the analysis proceeds with tests for cointegration of the REER series, based on the assumption of a unit root in all REER series. Johansen's testing procedure for co-integration and stability tests is used to identify whether the real fundamentals are sufficiently interrelated to find evidence for an equilibrium real exchange rate in the region. Based on the Hannan-Quinn information criterion (HQIC) method and the Schwarz Bayesian information criterion (SBIC) method, one lag is specified.

Johansen's testing procedure firstly tests for zero cointegrating equations and then accepts the first null hypothesis which cannot be rejected. In the specification with one lag and a constant trend, the null hypothesis of no cointegration is strongly rejected and we fail to reject the null hypothesis of at most two cointegrating equations. Consequently, we accept the null hypothesis that there are two cointegrating equations in the multivariate model. An estimation of the multivariate cointegrating vector errorcorrection model (VECM) for the REER series yields the parameters of the cointegrating vectors.

Table 3 presents the cointegration test results for the South American countries. The coefficients are large in both cointegrating equations and many have opposite signs, which emphasises large asymmetries in exchange rate adjustments. In the first equation, the coefficients of Colombia, Guyana, Paraguay and Uruguay are significant at the $1 \%$ level. Whilst the latter three countries remain significant at the same level, the coefficient of Colombia is insignificant in the second equation and instead, Chile has a significant coefficient. It is interesting to note that the significant coefficients are also the largest ones in relative size.

The eigenvalues of the companion matrix have been plotted to check the stability condition of the VECM estimates and identify whether the number of cointegrating equations has been correctly specified. Due to some of the eigenvalues appearing close to the unit circle, the stability check indicates that the model may be misspecified.

\footnotetext{
$8 \quad$\begin{tabular}{l|l} 
Marble \\
Research \\
Papers
\end{tabular}
} 
Table 3: Johansen testing procedure complete sample $(n=393)$

\begin{tabular}{|c|c|c|c|c|}
\hline Maximum rank & Eigenvalue & Trace statistic & $5 \%$ critical value & Lags \\
\hline 0 & - & 269.90 & 192.89 & 1 \\
\hline 1 & 0.2073 & 178.60 & 156.00 & \\
\hline 2 & 0.1540 & 112.88* & 124.24 & \\
\hline 3 & 0.0723 & 83.39 & 92.15 & \\
\hline 4 & 0.0645 & 57.17 & 68.52 & \\
\hline 5 & 0.0504 & 36.85 & 47.21 & \\
\hline $\begin{array}{l}\text { Normalised } \\
\text { coefficients }\end{array}$ & $\boldsymbol{\beta}$ & SE & a & SE \\
\hline Bolivia & 1 & - & 0.0000 & - \\
\hline Brazil & 0.0000 & (omitted) & 1 & - \\
\hline Chile & 1.0534 & 0.6044 & $-2.9936 *$ & 1.4844 \\
\hline Colombia & $-1.4633 * *$ & 0.4715 & 1.6591 & 1.1580 \\
\hline Ecuador & 0.4571 & 0.3047 & -0.9125 & 0.7485 \\
\hline Guyana & $-1.0838 * *$ & 0.1263 & $2.5083 * *$ & 0.3101 \\
\hline Paraguay & $2.9815^{* *}$ & 0.5062 & $-7.9597 * *$ & 1.2433 \\
\hline Venezuela & 0.1916 & 0.2130 & -0.2178 & 0.5233 \\
\hline Uruguay & $-1.9189 * *$ & 0.4528 & $5.4499 * *$ & 1.1122 \\
\hline Constant & -5.8132 & & 7.4671 & \\
\hline
\end{tabular}

Figures 3 and 4 allow for a visual inspection of the model's specification.

Figure 3: Linear prediction of difference over time

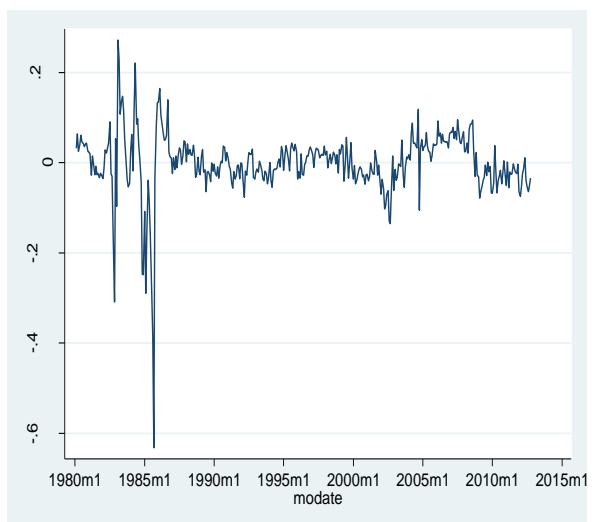

Figure 4: Predicted cointegrated equation over time

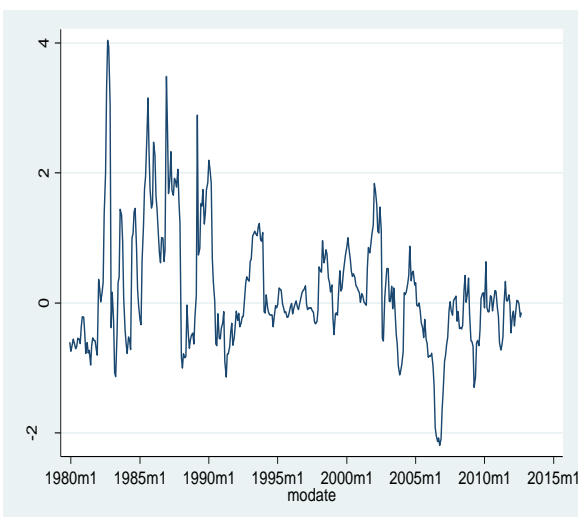

Note: All variables are monthly in logs. Base currency is a currency basket. The normalised coefficients are obtained after a Johansen normalisation restriction is imposed. $a$ and $\beta$ are coefficients for two distinct cointegration equations. Argentina, Peru, and Suriname are excluded due to data limitations. $* \mathrm{p}<.05, * * \mathrm{p}<.01$

The Viability of a Monetary Union in 
Graphing the cointegrating equations over time, the figures raise concern for increased"noise" during the Latin American debt crisis between 1980 and 1985. This adds to the observation of increased movement in the individual REER series during this period as identified above.

The presence of a structural break would bias the unit root tests. Further checks also indicate that the errors are not normally distributed and both skewed and kurtotic. Hence, the analysis is repeated omitting the crisis period to identify whether the tentative results are affected.

\subsubsection{Empirical results post-debt crisis sample}

Based on the FPE criterion and AIC criterion method, two lags are specified for the model omitting the crisis period. Following the steps of the analysis above, Johansen's testing procedure leads us to accept the hypothesis of at most one unique cointegration equation for the REER series. The presence of one single cointegrating equation aids the subsequent interpretation of the VECM parameters.

Table 4 displays the results of the cointegration test for the post crisis period. The coefficients are sizeably smaller compared to the full sample. Furthermore, five countries enter the equation with significant coefficients. Colombia, Guyana, and Venezuela are significant at the $1 \%$ level, Chile and Paraguay at the $5 \%$ level. Uruguay, which was significant in both equations of the complete sample above, is no longer significant in the reduced sample.

Table 4: Johansen testing procedure post-debt-crisis sample $(n=321)$

\begin{tabular}{|c|c|c|c|}
\hline Maximum rank & Eigenvalue & Trace statistic & $5 \%$ critical value Lags \\
\hline 0 & - & 218.03 & 192.89 \\
\hline 1 & 0.1922 & $149.50 *$ & 156.00 \\
\hline 2 & 0.1241 & 106.98 & 124.24 \\
\hline 3 & 0.0829 & 79.21 & 92.15 \\
\hline 4 & 0.0716 & 55.38 & 68.52 \\
\hline 5 & 0.0520 & 38.23 & 47.21 \\
\hline $\begin{array}{l}\text { Normalised } \\
\text { coefficients }\end{array}$ & $\boldsymbol{\beta}$ & SE & \\
\hline Bolivia & 1 & - & \\
\hline Brazil & 0.686 & 0.0732 & \\
\hline Chile & $0.5660 *$ & 0.2464 & \\
\hline Colombia & $-0.6972 * *$ & 0.1734 & \\
\hline Ecuador & 0.1331 & 0.0767 & \\
\hline Guyana & $-0.2462 * *$ & 0.0395 & \\
\hline Paraguay & $0.3627^{*}$ & 0.1465 & \\
\hline Venezuela & $-0.2083 * *$ & 0.0602 & \\
\hline Uruguay & -0.0134 & 0.1516 & \\
\hline Constant & -4.5882 & & \\
\hline
\end{tabular}


By default, the Johansen procedure imposes a constraint on the parameter of the first coefficient to be normalised to be unity. This leads to the interpretation that there exists an equilibrium relationship between the REER of Bolivia and the REERs of Brazil, Chile, Colombia, Ecuador, Guyana, Paraguay, Venezuela, and Uruguay. It is possible to redefine the model by constraining the coefficient of a different country. To see the result of an alternative normalisation, the VECM is re-estimated with the constraint imposed on Brazil, the largest economy in the sample.

Except from a change in the magnitude of the coefficients, the model remains the same. The new estimates of the parameters in the cointegrating equation are simply the previous estimates divided by 0.0686 (old coefficient of the newly normalised Brazil). This explains the large increase in the size of the coefficients. The alternative normalisation allows the interpretation of the estimates of the parameters in the cointegrating equation as providing evidence for an equilibrium relationship between the average monthly REER in Brazil and the REERs in the remaining countries.

The remainder of the analysis, which addresses another concern in the model, proceeds with Bolivia as the normalised country. The LM test clearly indicates serial correlation in the residuals. Based on Gonzalo (1994), serial correlation can stem from underspecifying the number of lags in a VECM. Therefore, the model is re-estimated using four rather than two lags. The output is displayed in table 5.

Table 5: Johansen testing procedure with additional lags

\begin{tabular}{|l|l|l|}
\hline Lags & \multicolumn{2}{l|}{ Obs } \\
\hline 4 & 321 & \\
\hline Normalised coefficients & $\boldsymbol{\beta}$ & SE \\
\hline Bolivia & 1 & - \\
\hline Brazil & $0.3001 * *$ & 0.1070 \\
\hline Chile & -0.0166 & 0.3720 \\
\hline Colombia & $-1.3420 * *$ & 0.2624 \\
\hline Ecuador & $0.2754 *$ & 0.1095 \\
\hline Guyana & $-0.1562 * *$ & 0.0595 \\
\hline Paraguay & 0.3050 & 0.2182 \\
\hline Venezuela & $-0.2978 * *$ & 0.0883 \\
\hline Uruguay & $0.6659 * *$ & 0.2220 \\
\hline Constant & -3.5216 & \\
\hline
\end{tabular}

Note: All variables are monthly in logs. Base currency is a currency basket. The normalised coefficients are obtained after a Johansen normalisation restriction is imposed. $\beta$ is the estimated coefficient of the cointegrating equation. Argentina, Peru, and Suriname are excluded due to data limitations. * $\mathrm{p}<.05, * * \mathrm{p}<$ .01 .

In comparison with the model with only two specified lags, the number of significant coefficients has increased from five to six, five of which are significant at the $1 \%$ level. There is again a different combination of countries with significant coefficients. Colombia, Guyana, and Venezuela are the only countries consistently significant in the post-crisis sample. Overall, most coefficients tend to have 
increased in size. The results of the Jarque-Bera test are against unchanged and indicate that we can strongly reject the null hypothesis of normally distributed errors. Most of the errors are also both skewed and kurtotic.

\section{Discussion}

Enders and Hurn's model only provides little guidance with respect to interpreting the cointegration results and a formal benchmark for the interpretation of the coefficients is missing. Whilst Enders and Hurn (1994) clearly state that evidence for a cointegration relationship is necessary to make the case for a monetary union, they do not address the required size of the coefficients in the cointegration equation. Yet, it is obvious that large coefficients would be a signal for large asymmetries and would therefore not be a good indicator for the viability of a common currency. Determining such a threshold remains a challenge.

Whilst there is clear evidence for a cointegration relationship among the nine South American countries, it is difficult to interpret multiple cointegration vectors, as found in part one of the above analysis. Therefore, the focus of the interpretation lies on the reduced sample spanning from 1986 to 2012.

Leaving out the period of the Latin American debt crisis in the early 1980s, a clear cointegrating relationship with a single cointegration vector is found (table 4). Five of eight coefficients are statistically significant at the $5 \%$ level. Nevertheless, the results reveal sizeable asymmetries in the adjustments of the real exchange rates. The empirical results indicate that a $1 \%$ rise in the Bolivian boliviano (real depreciation) is associated with a $0.07 \%$ depreciation of the real value of the Brazilian real, a $0.57 \%$ depreciation of the real value of the Chilean peso, a $0.13 \%$ depreciation of the real value of Ecuador's currency 3 , and a $0.36 \%$ depreciation of the real Paraguayan guarani, but a $0.7 \%$ appreciation of the real Colombian peso, a $0.25 \%$ appreciation of the real Guyanese dollar, a $0.21 \%$ appreciation of the real Venezuelan bolivar, and a $0.01 \%$ appreciation of the real Uruguayan peso. The results show that Bolivia appears to be most closely linked with Brazil, whilst the largest REER adjustment asymmetry lies between Bolivia and Colombia.

The negative coefficients for half of the countries in the sample indicate that these countries' REER adjust in the opposite direction, compared to Bolivia's. One would expect that if countries are to be integrated under the same monetary policy, it is desirable that their currencies move in similar ways. Hence, negative coefficients are a negative indicator for the viability of a common currency.

Based on the above analysis, the motivation for monetary integration is only modestly justified from GPPP perspective. The UNASUR members in the sample appear to constitute an economically linked region experiencing common real macroeconomic shocks. Possible linkages between the countries may include technology transfers, immigration, and capital movements. Despite the cointegration of their REERs, sizeable adjustment asymmetries remain.

\section{Limitations}

As data is missing for Argentina, Peru, and Suriname, the conclusions drawn from the analysis cannot be generalised for the overall UNASUR group. Whilst Peru and Suriname have small economies, Argentina's economy plays a strong role in the region and its inherent instability along several lines is likely to have

\footnotetext{
3 Following a severe economic crisis and large-scale depreciation of its currency, the Ecuadorian sucre was replaced by the US dollar as national currency in 2000 . The sample comprises periods of both currencies as legal tender. 
a major impact on the analysis. Including the three countries into the analysis might therefore change the results drawn in this paper, and any political conclusions drawn from this report have to take this into account.

Additionally, no data for a base currency within the country set was available and a basket of currencies was used as a substitute. Future research may improve the analysis by using a currency within the bloc as base currency. The Brazilian real would be a suitable choice due to the country's economic leadership in the region.

\section{Concluding remarks}

Policymakers within the UNASUR continue to support the efforts of greater political and economic integration within South America. Despite the plans for monetary integration being interrupted by the uncertainties surrounding the euro, the idea of a common currency within the UNASUR has recently returned to the political agenda. During the opening of the UNASUR VIII summit in December 2014, Ecuador's President Correa reiterated the desirability of a common currency further stating that "a United Latin America is not a dream anymore, but the only way to reach our independence".

The purpose of this thesis was to analyse whether the driving factors of the UNASUR member countries' real exchange rates are sufficiently interrelated to advocate a common currency. The G-PPP-based analysis has shown that there exists a cointegration relationship with multiple cointegration vectors among the countries in the sample based on the complete sample from 1979 to 2012. Due to increased noise in the real exchange rate series during the Latin American debt crisis in the early 1980s, the analysis was repeated excluding the 1979-1985 period. In the reduced sample, a unique cointegrating relationship between the monthly REERs of Brazil, Bolivia, Chile, Colombia, Ecuador, Guyana, Paraguay, Venezuela, and Uruguay is evident. Despite apparent asymmetries in the adjustment of the countries' real exchange rates, evidence for the viability of a common currency has thus been found.

Nevertheless, the strong variation in development stages of UNASUR countries along with frequent and prolonged periods of economic and political instability across the region continue to threaten the prospects of a monetary union. Taking into account the negative experience with economic and political heterogeneity among member states in the Eurozone, caution is advised in the UNASUR case. The formation of a monetary union in South America therefore remains uncertain. 


\section{References}

Bayoumi, T., Lee, J., \& Jayanthi, S. (2006). New Rates from New Weights. IMF Staff Papers, 53(2). Retrieved from https://www.imf.org/External/Pubs/FT/staffp/2006/02/pdf/bayoumi.pdf

Berg, A., Borensztein, E., \& Mauro, P. (2003). Monetary Regime Options for Latin America. International Monetary Fund. Retrieved from http://www.imf.org/external/pubs/ft/fandd/2003/09/pdf/berg.pdf

CAF. (2015). About CAF. Retrieved from CAF Development Bank of latin America: http://www.caf.com/en/aboutcaf/who-we-are/

Council of Hemispheric Affairs. (2013, September 3). 21st Century Regionalism: Where is Latin America headed? . Retrieved from COHA Research: http://www.coha.org/21st-century-regionalism-where-is-latin-americaheaded/

Enders, W., \& Hurn, S. (1994). The Theory of Generalized Purchasing Power Parity: Tests in the Pacific Rim. Review of International Economics, 179-190.

Frenkel, R., \& Rapetti, M. (2010). A Concise History of Exchange Rate Regimes in Latin America. Washington: Center for Economic and Policy Research. Retrieved from http://www.cepr.net/documents/publications/exchangerates-latin-america-2010-04.pdf

Kenen, P. B. (1969). The theory of optimum currency areas: an eclectic view. In R. A. Mundell, \& A. K. Swoboda, Monetary Problems of the International Economy (pp. 41-60). Chicago: University of Chicago Press.

McKinnon, R. I. (1963). Optimum currency areas. American Economic Review, 53, 717-725.

Mundell, R. A. (1961). A theory of optimum currency areas. American Economic Review, 53, 657-665.

OAS. (2015). Purpose. Retrieved from Organization of American States: Democracy for peace, security, and development: http://www.oas.org/en/about/purpose.asp

Peña, F. (2009, April). South American Integration, Can Unasur and Mercosur complement each other? Retrieved from http://www.felixpena.com.ar/index.php?contenido=wpapers\&wpagno=documentos/2009-04-south-americanintegration-unasur-mercosur

Wilson, P., \& Choy, K. M. (2007). Prospects for enhanced exchange rate cooperation in East Asia: some preliminary findings from generalised PPP theory. Applied Economics, 39, 981-995. doi: 10.1080/00036840500497042 